\title{
KOMENTAR UJARAN KEBENCIAN PADA BERITA IMIGRAN JERMAN DALAM FACEBOOK
}

\author{
Lessy Ginsena $^{1}$, Erna Triswantini ${ }^{2}$
}

${ }^{1,2}$ Universitas Negeri Jakarta

1'lessyginsena@gmail.com, 2etriswantini@unj.ac.id

\section{Article Info}

\section{Article history:}

Received 15 Desember 2020

Accepted 10 Februari 2021

Published 1 April 2021

\section{Keyword:}

Ujaran Kebencian,

Komentar Facebook,

Imigran Jerman.

\section{Abstract}

This study discusses how hate speech comments on German immigrant news in social media Facebook. The purpose of the study is to describe hate speech on German immigrant news in social media Facebook and its forms in the comments column on Facebook. The study uses descriptive qualitative research and illocutionary speech act theory analysis. The results showed that the forms of hate speech found were rassismus and fremdenfeindlichkeit, antisemitismus and antimuslimischer rassismus, sexismus, homo and transphobie, and active politick. The most common hate speech found is politic aktive, namely hatred towards the German government and activists who defend minorities. The most common illocutionary acts found were expressive illocutionary acts in the form of satire for the German government, which according to them, prioritized immigrants over German society.

Penelitian ini membahas tentang bagaimana komentar ujaran kebencian pada berita imigran Jerman dalam media sosial facebook. Tujuan penelitian ini adalah untuk mendeskripsikan ujaran kebencian pada berita imigran Jerman dalam media sosial facebook dan bentuk-bentuknya dalam kolom komentar di Facebook. Metode penelitian ini menggunakan jenis penelitian kualitatif deskriptif dan menggunakan analisis teori tindak tutur ilokusi. Hasil penelitian menunjukkan bahwa bentuk-bentuk ujaran kebencian yang ditemukan adalah rassismus dan fremdenfeindlichkeit, antisemitismus dan antimuslimischer rassismus, sexismus, homo dan transphobie, serta politisch aktive. Ujaran kebencian yang paling banyak ditemukan adalah politisch aktive, yaitu sikap benci kepada pemerintah Jerman dan aktivis yang membela kaum minoritas. tindak ilokusi yang paling banyak ditemukan adalah tindak ilokusi ekspresif berupa sindiran untuk pemerintah Jerman yang menurut mereka memprioritaskan imigran daripada masyarakat Jerman sendiri.

Copyright () 2021 Jurnal Ilmu Komunikasi. All rights reserved

Editorial Office:

Program Studi Ilmu Komunikasi, Fakultas Dakwah dan Komunikasi, UIN Sunan Ampel Surabaya. Jl. Ahmad Yani 117 Surabaya, Jawa Timur, Indonesia.

Email: jurnalilkom@uinsby.ac.id 


\section{Pendahuluan}

Bahasa memiliki peran penting dalam kehidupan yang dijadikan sebagai alat komunikasi antar setiap makhluk hidup. Melalui bahasa, manusia dapat mengekspresikan segala pemikiran dan gagasan yang dimilikinya. Agar komunikasi antar makhluk hidup dapat berjalan secara efektif, diperlukan adanya pemahaman bahasa antara penutur dan mitra tutur. Sehingga melalui proses pertukaran informasi tersebut, diharapkan penutur dan mitra tutur dapat mencapai tujuan komunikasi yang diinginkan. Bahasa sebagai sarana berkomunikasi berkaitan erat dengan pragmatik, yaitu cabang ilmu linguistik dengan pengkajian makna di luar bahasa. Dalam ilmu pragmatik terdapat unsur yang meneliti kaitan antara peserta dalam percakapan yaitu penutur dan mitra tutur didasarkan dengan konteks pertuturan. Unsur tersebut dinamakan tindak tutur ilokusi.

Tindak tutur ilokusi merupakan suatu wujud kegiatan komunikasi yang terjadi apabila terdapat penutur dan mitra tutur, serta mengandung maksud dan tujuan tertentu. Wijana ${ }^{1}$ mengatakan bahwa tindak tutur ilokusi lebih sukar untuk diidentifikasikan karena harus mempertimbangkan konteks atau situasi tutur seperti penutur, mitra tutur, tempat dan waktu terjadinya pertuturan. Perkembangan teknologi dan informasi di

1 Yendra, Mengenal Ilmu Bahasa (Linguistik), 1st ed. (Yogyakarta: Deepublish, 2018), 242-243.

2 Nurul Rizky and Sri Dewi Setiawati, "Penggunaan Media Sosial Instagram Haloa Cafe Sebagai Komunikasi Pemasaran Online," Jurnal era digital memberikan kemudahan masyarakat dalam komunikasi melalui media elektronik. Media ini menyajikan berbagai kemudahan untuk berkomunikasi dengan mitra tutur yang berada di tempat yang jauh dari penutur. Pertuturan tidak hanya terjadi pada dialog tatap langsung, tetapi juga bisa melalui media sosial yang ditunjang menggunakan internet. Internet dapat menghilangkan adanya batas jarak dan waktu seseorang dalam memperoleh informasi. Sehingga setiap orang akan mudah berkomunikasi kapan pun dan di mana pun. ${ }^{2}$ Pada tahun 2019 media sosial yang paling aktif digunakan warganet adalah Facebook. ${ }^{3}$

Pengguna Facebook dapat saling berinteraksi melalui komentar pada postingan berita atau berkirim pesan secara langsung. Dalam komunikasi melalui media sosial juga kesantunan dalam berbahasa. Apabila kesantunan berbahasa tersebut tidak berhasil diwujudkan, maka akan menimbulkan berbagai komentar negatif, seperti mengandung ujaran kebencian.

Menurut Komisi Eropa (Badan eksekutif Uni Eropa yang bertanggung jawab untuk menegakkan hukum di Uni Eropa) melawan Rasisme dan Intolerensi menjelaskan bahwa ujaran kebencian merupakan hasutan negatif yang dilakukan oleh sekelompok orang kepada kelompok lain berdasarkan pada ras seseorang, warna kulit, jenis kelamin, agama atau

Ilmu Komunikasi 10, no. 2 (2020): 178, https://doi.org/10.15642/jik.2020.10.2.177-190.

${ }^{3}$ Michael A Stelzner, "2019 Social Media Marketing Industry Report," Social Media Examiner, May, 2019, https://drive.google.com/file/d/1znPGOq0IGdJVJlI 7rbhimpL7gk-Gh-vL/view?usp=sharing. 
kepercayaannya, keturunan atau asal kebangsaan maupun suatu etnis tertentu. ${ }^{4}$

Di Jerman misalnya, berita mengenai imigran diawali dengan adanya kebijakan yang dibuat oleh Angela Merkel selaku kanselir wanita pertama di Jerman. Pada 2015 , terdapat suatu kebijakan yang dibuat oleh Angela Merkel untuk membantu memberikan kehidupan yang layak kepada para pengungsi terdampak perang yang disebut "Die Politik der offenen Tür" atau "Politik Pintu terbuka". Jerman bekerjasama dengan negara-negara di Eropa, seperti Yunani dan negara di luar Eropa, seperti Turki untuk membantu menjalankan kebijakan tersebut. Negara Turki dijadikan sebagai negara transit para imigran dan Yunani dijadikan sebagai tempat penampungan sementara imigran sebelum direlokasikan ke negara-negara Eropa.

Sejak adanya kebijakan politik pintu terbuka, pemerintah Jerman hingga kini kerap kali membantu para imigran yang membutuhkan bantuan kemanuasiaan. Menurut Kantor Federal untuk Migrasi dan Pengungsi mengatakan bahwa ketiga negara asal imigran didominasi oleh negara Suriah, Irak, dan Afganistan. ${ }^{5}$ Kemudian

${ }^{4}$ ECRI, Allgemeine Politik-Empfehlung Nr. 15 über die Bekämpfung von Hassrede (Straßburg: 2016), 3, https://rm.coe.int/ecri-general-policyrecommendation-no-15-on-combating-hatespeech-germ/16808b5b00.

5 BAMF, "Aktuelle Zahlen," accessed March 15, 2020,

https://www.bamf.de/SharedDocs/Anlagen/DE/Sta tistik/AsylinZahlen/aktuelle-zahlen-januar2020.pdf? blob=publicationFile \& v $=3$.

${ }^{6}$ Hans Eckhard, Das Bundesamt in Zahlen (Kassel: Silber Druck oHG, 2019), chap. 1, 28, https://www.bamf.de/SharedDocs/Anlagen/DE/Sta tistik/BundesamtinZahlen/bundesamt-in-zahlen- agama para imigran didominasi oleh agama Islam. ${ }^{6}$

$\begin{array}{crcr}\text { Media } & \text { sosial } & \text { Facebook dapat } \\ \text { dijadikan } & \text { sebagai } & \text { wadah dalam }\end{array}$
mempublikasikan berita seperti pada akun berita Deutsche Welle (DW) di Facebook. $D W$ merupakan salah satu media informasi dari Jerman yang mempublikasikan berita terbaru di Facebook. Pada 9 Maret 2020 akun DW Deutsch di Facebook menginformasikan berita mengenai kebijakan baru yang dilakukan pemerintah Jerman. $^{7}$

Kebijakan baru tersebut berhubungan dengan imigran muda. Kebijakan tersebut diawali karena adanya desakan dari Komisi Eropa pada 23 Desember 2019. Komisi Eropa mendesak pemerintah Jerman untuk membantu anakanak pengungsi di bawah umur yang hidup di kamp Yunani tanpa orang tua mereka. Kemudian pemerintah Jerman menerima permintaan dari Komisi Eropa dengan membantu 1000 hingga 1500 pengungsi muda di bawah umur yang membutuhkan bantuan kemanusiaan. Hal tersebut tentunya mendapatkan beragam tanggapan dari masyarakat. ${ }^{8}$

2019.pdf; jsessionid=E3ADB4C62E61A4EE84648 4041A9DC1EF.internet552?_blob=publicationFil $\mathrm{e} \& \mathrm{v}=5$.

7 DW Deutsch, "Deutschland will jungen Flüchtlingen helfen," Facebook, March 9, 2020 , https://m.facebook.com/dw.german/posts/1015726 7668292956/.

${ }^{8}$ Deutsche Welle, "Deutschland will jungen Flüchtlingen helfen," accessed April 5, 2020, https://www.dw.com/de/deutschland-will-jungenfl\%C3\%BCchtlingen-helfen/a52688183?fbclid=IwAR2YTEgn59Zc4NUOTXTo5uDHom_ByTgc317NoDnUDSsaDEwtiseOIe nZxg. 
Pada penelitian ini, peneliti ingin mengetahui bentuk-bentuk ujaran kebencian yang terdapat pada komentarkomentar warganet di akun Facebook DW Deutsch pada artikel berita imigran. Artikel berita tersebut dipublikasikan pada 9 Maret 2020 pukul 15:33 WIB.

\section{Kajian Pustaka}

\section{Tindak Tutur}

Menurut Kessel \& Reimann teori dalam pragmatik yang memberikan kontribusi penting adalah teori tindak tutur. ${ }^{9}$ Kushartanti menjelaskan mengenai tindak tutur yang dikatakan sebagai komponen dalam bahasa. Komponen tersebut berupa perbuatan berbahasa peserta dalam pertuturan, bentuk menyapaikan amanat, topik pertuturan, dan konteks amanat yang disampaikan. ${ }^{10}$

Dari pendapat tersebut diketahui bahwa pertuturan atau tindak tutur melibatkan suatu tindakan komunikasi yang terjadi secara dua arah dan akan dapat terlaksana apabila terdapat penutur dan mitra tutur di dalam percakapn. Tindakan yang disampaikan oleh penutur kepada mitra tutur dapat berupa amanat, topik, dan konteks yang menyangkut amanat dalam percakapan tersebut. Jadi, tindak tutur merupakan suatu tindakan dalam berbahasa yang diujarkan oleh penutur kepada lawan bicaranya (mitra tutur). dengan maksud menginformasikan atau mengutarakan keinginan penutur kepada

9 Katja Kessel and Sandra Reimann, Basiswissen Deutsche Gegenwartssprache, 5th ed. (Tübingen: Narr Francke Attempto Verlag GmbH + Co. KG, 2017), 232-233.

10 Kushartanti, Pesona Bahasa, 3rd ed. (Jakarta: PT. Gramedia Pustaka Utama, 2009), 109. mitra tutur sebagai bagian dari proses penyampaian komunikasi.

\section{Komponen Tindak Tutur}

Secara umum Austin membagi pertuturan atau tindak tutur menjadi 3 jenis, .yaitu tindak tutur lokusi, tindak tutur ilokusi, dan tindak tutur perlokusi. Pertuturan lokusi atau yang biasa disebut dengan tindak tutur lokusi (Der lokutionäre $A k t$ ) didefinisikan sebagai "Die Äußerung eines Satzes". Kalimat tersebut diartikan sebagai ucapan yang terdapat dalam sebuah kalimat. Pertuturan ilokusi atau tindak tutur ilokusi (Der Illokutionäre Akt) didefinisikan sebagai "Der Akttyp, der durch die Äußerung durchgefuhrt wird" atau jenis tindakan yang dilakukan dari kalimat yang diujarkan yang dapat berupa sebuah pernyataan, tawaran, perintah, peringatan, hingga kalimat yang menggunakan kata kerja performatif.

Sedangkan pertuturan perlokusi atau tindak tutur perlokusi (Der Perlokutionäre $A k t$ ) adalah efek berupa tindakan yang ditimbulkan dari adanya tindak ilokusi seperti saat mitra tutur menerima tawaran atau menjalankan perintah yang diberikan oleh penutur. Untuk memahami perbedaan dari ketiga komponen tindak tutur terdapat contoh yang dikemukakan oleh Austin. ${ }^{11}$

"Gib mir einen Apfel!'

("Berikan saya sebuah apel!") Tindak lokusi : "Gib mir einen Apfel!"

\footnotetext{
${ }^{11}$ Manfred Krifka, Sprechakte und Satztypen in Hauptseminar Sommersemester (Berlin: University of Humbolt, 2004), chap. 2, https://amor.cms.huberlin.de/ h2816i3x/Lehre/2005_HS_Sprechakte/ Sprechakte_01_02_Einfuehrung_Austin.pdf.
} 
Tindak ilokusi : Perintah.

Tindak perlokusi : A memberikan S sebuah apel.

Berdasarkan contoh kalimat di atas diketahui bahwa $\mathrm{S}$ (penutur) meminta sesuatu kepada A (mitra tuturnya). Tindak lokusi yang ada berupa kalimat pernyataan yang diujarkan S kepada A. Tindak ilokusi yang terkandung merupakan sebuah perintah karena, $\mathrm{S}$ (penutur) berusaha untuk memerintahkan A (mitra tutur) untuk memberikan sebuah apel kepadanya. Sedangkan tindak perlokusi yang dimunculkan berupa adanya tindakan yang dilakukan A (mitra tutur) kepada $\mathrm{S}$ (penutur) yaitu dengan A memberikan sebuah apel yang diminta oleh $\mathrm{S}$.

Berdasarkan teori-teori yang telah dijelaskan. di atas didapat kesimpulan bahwa terdapat tiga komponen umum yang mendasar dari tindak tutur. Ketiga komponen tersebut adalah tindak tutur lokusi, tindak tutur ilokusi, dan tindak tutur perlokusi. Tindak tutur lokusi dikatakan sebagai komponen yang mendasar dari ketiga tindak tutur. Saat seseorang telah memiliki maksud atau tujuan tertentu kepada orang lain untuk mengungkapkan sesuatu hal itulah yang dinamakan tindak lokusi. Tindak lokusi tersebut dapat berupa pernyataan atau ucapan yang disampaikan penutur kepada mitra tuturnya. Komponen pertuturan selanjutnya adalah tindak ilokusi. Pertuturan ini berupa jenis tindakan yang muncul sebagai akibat adanya tindak lokusi. Dengan kata lain seorang mitra tutur akan mengetahui

12 Baryadi, I. Praptomo, Kalimat Tidak Berklausa dalam Bahasa Indonesia, Jurnal Widyaparwa, 47 no 1 (Juni 2019): 60-61, maksud dan tujuan lain yang diutarakan penutur kepadanya.

Maksud dan tujuan tersebut dapat berupa sebuah permohonan, perintah, protes, janji, peringatan atau mungkin hanya sekedar menyampaikan informasi saja. Komponen tindak tutur yang terakhir adalah tindak perlokusi yang diketahui sebagai efek yang akan ditimbulkan dari adanya tindak lokusi dan ilokusi yang diterima mitra tutur. Mitra tutur akan melaksanakan suatu tindakan yang diutarakan penutur kepadanya.

\section{Fungsi Tindak Ilokusi}

Tindak tutur ilokusi memiliki empat fungsi, yaitu konvivial, kolaboratif, kompetitif dan konfliktif. ${ }^{12}$

a. Konvivial berupa menawarkan, menyapa, memaafkan, menyetujui dan menghargai.

b. Kolaboratif berupa melaporkan, mengumumkan, memberitahukan, menginformasikan dan menguraikan.

c. Kompetitif berupa memerintah, meminta, melarang, menilai, menasihati dan menyindir.

d. Konfliktif berupa mengancam, menuduh, mengejek, membentak dan mengumpat.

Dari keempat fungsi tersebut berkaitan dengan tujuan sosial yang berupa perilaku sopan santun para pelaku percakapan. Pada fungsi ilokusi competitive, sopan santun bernilai negatif. Meskipun demikian, sopan santun berguna

https://widyaparwa.com/index.php/widyaparwa/art icle/download/291/pdf_1. 
untuk mengurangi ketidakharmonisan yang secara tidak langsung terkandung dalam percakapan.

Sedangkan pada fungsi convivial, sopan santun bernilai positif. Sopan santun pada fungsi tersebut berguna untuk menyampaikan ramah tamah. Kemudian pada fungsi collaborative, tidak bersangkut-paut dengan sopan santun karena dinilai netral pada tujuan sosial. Pada fungsi conflictive sama sekali tidak terdapat sopan santun karena bertujuan untuk menimbulkan masalah. ${ }^{13}$

\section{Ujaran Kebencian}

Menurut Meibauer ujaran kebencian merupakan ungkapan bermakna negatif yang ditujukan seorang individu atau kelompok kepada individu atau kelompok tertentu. Dengan maksud menjelekkan atau menghasut orang untuk membenci seseorang ataupun kelompok masyarakat tertentu. ${ }^{14}$ PBB menjelaskan bahwa ujaran kebencian dipahami sebagai segala jenis komunikasi, baik lisan, tulisan maupun perilaku yang bertujuan menyerang atau menggunakan bahasa yang merendahkan seseorang atau sekelompok orang, atas dasar suku, agama, ras, kebangsaan, warna kulit atau faktor identitas lainnya. ${ }^{15}$ Siri mengatakan bahwa media sosial kini sudah

${ }^{13}$ Geoffry Leech, Principles of Pragmatics, $1^{\text {st }}$ ed. (New York: Longman Inc, 2014), chap. 5.

14 Jörg Meibauer, Hassrede/Hate Speech Interdisziplinäre Beiträge zu Einer Diskussion (Giessen: Elektronische Bibliothek, 2013), chap. 1, http://geb.uni-

giessen.de/geb/volltexte/2013/10121/pdf/Hassrede Meibauer_2013_korr.pdf\#page $=10$.

15 "Strategy and Plan of actions on Hate Speech," United Nations, accessed August 14, 2021,

https://www.un.org/en/genocideprevention/docum menjadi sebuah tempat yang sering digunakan untuk ajang adu komentar. Perdebatan tersebut dapat berupa mengenai gender ataupun pengungsi. Bahkan beberapa komentar dinilai sangat kreatif, karena para pengguna media sosial dapat dengan mudahnya mengeluarkan kata umpatan maupun penghinaan terhadap orang lain. ${ }^{16}$

Sehingga dapat disimpulkan bahwa ujaran kebencian adalah ungkapan dengan maksud menjelekkan, menghasut, menghina atau merendahkan orang lain baik secara langsung maupun tidak langsung dan media sosial merupakan tempat yang dapat dijadikan sebagai ajang perdebatan para penggunanya, bahkan tidak jarang mereka mengeluarkan katakata umpatan dan penghinaan kepada seseorang.

\section{Bentuk-Bentuk Ujaran Kebencian}

Menurut lembaga promosi pendidikan nasional dan perlindungan anak dan remaja legal menjelaskan lebih lanjut mengenai bentuk-bentuk ujaran kebencian sebagai berikut. ${ }^{17}$

a. Rassismus dan Fremdenfeindlichkeit; rasisme dapat dikatakan sebagai doktrin yang dimunculkan oleh individu untuk membedakan individu

ents/UN\%20Strategy\%20and\%20Plan\%20of\%20 Action\%20on\%20Hate\%20Speech\%2018\%20June $\% 20 S Y N O P S I S . p d f$.

16 Jasmin Siri, Kampfzone Gender (Berlin: Nicolai Publishing \& Intelligence $\mathrm{GmbH}, 2018$ ), 43.

17 AJS NRW. Hate Speech Hass im Netz (Wuppertal: Börje Halm Press, 2019), chap. 2, https://doi.org/10.4324/9781315699868-310. 
lainnya berdasarkan ras seperti warga Jerman yang menganggap ras mereka adalah ras yang paling unggul diantara ras lainnya.

Xenofobia

(Fremdenfeindlichkeit)

dapat dikatakan sebagai rasa takut atau tidak suka terhadap orang asing yang bukan berasal dari wilayah mereka seperti warga Jerman yang tidak suka dengan adanya imigran di negara Jerman.

b. Antisemitismus dan Antimuslimischer Rassismus; ujaran kebencian dalam bentuk menyerang dan merendahkan agama seseorang pada umumnya terkait erat dengan rasismus. Antisemitisme dikatakan sebagai sikap benci atau tidak suka yang ditujukan kepada kaum Yahudi, sedangkan anti muslim dikatakan sebagai sikap benci dan prasangka buruk yang ditujukan kepada kaum muslim.

c. Sexismus; bentuk ujaran kebencian ini mengacu pada diskriminasi dan devaluasi perempuan dan anak perempuan berdasarkan jenis kelamin mereka.

d. Homo-dan Transphobie; transseksual, interseksual, dan homoseksual dapat terkena dampak diskriminasi berdasarkan gender atau orientasi sosial. Bahkan kaum muda dengan orientasi seksual seperti ini juga beresiko menjadi korban permusuhan, devaluasi, kekerasan serta penindasan di dunia maya. Mereka yang resah dengan resiko seperti ini dapat dengan mudah kehilangan harga diri yang dibutuhkan pada fase ini untuk mengendalikan tubuh dan seksualitas mereka. Ujaran kebencian yang diterima oleh mereka yang memiliki orientasi seksual seperti ini yaitu mereka dikaitkan dengan adanya kejahatan pedoseksual, inses, atau sodomi.

e. Politisch Aktive; bentuk ujaran ini mempengaruhi mereka yang berjuang untuk melawan misantropi online dan offline atau yang berkomitmen untuk membantu masyarakat seperti pembantu, imgran, aktivis, atau politisi yang kritis terhadap feminis dan rasisme. Para pembela seringkali mendapatkan komentar berupa penghinaan dan ancaman penuh kebencian. Kaum muda yang ikut membela masyarakat juga dapat terkena dampak dimusuhi oleh masyarakat.

Beberapa bentuk-bentuk ujaran kebencian tersebut diperlukan agar nantinya mudah dalam mengklasifikasi sebuah ujaran negatif yang dinyatakan sebagai ujaran kebencian. Dari berbagai macam bentuk-bentuk tersebut disimpulkan bahwa ujaran kebencian dapat terjadi pada semua golongan masyarakat seperti politisi, jurnalis, aktivis, pembantu, imigran, orang-orang dengan orientasi seksual yang berbeda, serta kaum muda.

\section{Metode Penelitian}

Pada penelitian ini menggunakan metode penelitian thematic analysis kualitatif. Thematic analysis merupakan cara yang digunakan untuk menganalisa data yang memiliki tujuan 


mengidentifikasi tema-tema tertentu
kemudian data dikumpulkan oleh
peneliti. ${ }^{18}$

Tahapan-tahapan dalam thematic analiysis ini adalah; Pertama, memahami data, yakni data penelitian berupa komentar yang secara langsung menanggapi artikel berita dan komentar dipilih berdasarkan kriteria bentuk-bentuk ujaran kebencian menurut lembaga promosi pendidikan nasional dan perlindungan anak dan remaja legal.

Kedua, pada tahap ini peneliti melakukan kode (coding) data. Dalam hal ini terdapat lima kriteria ujaran kebencian seperti Rassismus dan Fremdenfeindlichkeit, Antisemitismus dan Antimuslimischer Rassismus, Sexismus, Homo- dan Transphobie, serta Politisch Aktive.

Ketiga, pada tahap akhir thematic analysis ini adalah mencari tema, dalam mencari tema ini peneliti menggambarkan sesuatu yang sangat penting yang ada di data terkait, sesuai dengan masalah yang diteliti atau sesuai dengan pola fenomena yang diteliti yaitu 82 komentar dipilih 25 komentar yang memenuhi kriteria bentukbentuk ujaran kebencian. Maka data tema penelitian adalah komentar-komentar yang mengandung ujaran kebencian

\section{Hasil dan Pembahasan}

Berdasarkan hasil .penelitian. .yang telah dilakukan, ditemukan beberapa bentuk ujaran kebencian yang terkandung dalam komentar warganet di Fanpage DW

${ }^{18}$ Braun, V., \& Clarke, V., "Using thematic analysis in psychology. Qualitative Research in
Deutsch. Pada beberapa komentar diperoleh setidaknya 1 hingga 3 bentuk ujaran kebencian. Dari komentar tersebut memiliki fungsi ilokusi yang berbedabeda. Dalam penelitian ini nama penutur akan ditulis dengan inisial " $\mathrm{X}$ " dan diurutkan sesuai dengan data yang akan dibahas, sedangkan deskripsi penutur akan ditulis singkat menjadi DP.

Berdasarkan klasifikasi ujaran kebencian AJS NRW (2016: 6-11) diperoleh sebanyak 10 data mengandung ujaran kebencian Politisch Aktive karena ditandai dengan sikap penutur yang tidak setuju terhadap kebijakan yang dilakukan pemerintah Jerman dan penutur juga tidak suka dengan para aktivis yang membela imigran sehingga atas tanda tersebut diklasifikasikan dalam ujaran kebencian Politisch Aktive.

Ujaran kebencian ini bertujuan untuk menyerang pihak politisi dan aktivis yang membela para imigran dibawah umur. Penutur secara tidak langsung menunjukan sikap tidak suka terhadap pemerintah Jerman. Penutur menilai bahwa kebijakan politik pintu terbuka pada 2015 sebagai awal adanya kebijakan lain dari pemerintah Jerman guna membantu para imigran yang membutuhkan seperti pada kebijakan ini. Pemerintah Jerman kembali membantu para imigran dengan merelokasikan mereka ke Jerman. Berikut ini merupakan contoh ujaran kebencian Politisch Aktive yang terdapat dalam penelitian ini.

X1: "Dann rollt ja der Rubel endlich

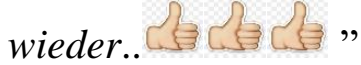

Psycology," Research Repository 3 (2) (December 2006): 78, https://doi.org/10.1191/1478088706qp063oa. 
DP: Orang Jerman, tidak menyukai imigran dan partai $C D U$.

Pada komentar tersebut memiliki makna "Maka uang akhirnya harus mengalir kembali“". Penutur menilai bahwa pemerintah Jerman kerap kali menghabiskan perekonomian untuk membantu para imigran. Komentar tersebut adalah ujaran kebencian dengan maksud merendahkan pemerintah Jerman atas kebijakan membantu para imigran. Komentar tersebut juga berfungsi untuk menyindir pemerintah Jerman. Sindiran ditunjukkan melalui kata wieder atau "Kembali". Pada kata tersebut penutur secara tidak langsung menyindir pemerintah bahwa perekonomian yang dimiliki pemerintah Jerman hanya dihabiskan untuk mengurusi kebutuhan para pencari suaka saja. Dengan kata lain, penutur yang merupakan orang Jerman merasa cemburu karena pemerintah kembali mengeluarkan dana untuk membantu kaum imigran.

Pada hasil penelitian berikutnya diperoleh 2 data mengandung ujaran kebencian Politisch Aktive dan Fremdenfeindlichkeit karena ditemukan tanda bahwa penutur tidak suka dengan adanya imigran sebagai orang asing di Jerman dengan begitu penutur menyalahkan pemerintah atas kebijakan relokasi imigran ke Jerman yang dinilai penutur hanya menguntungkan imigran saja maka atas tanda tersebut komentar dapat diklasifikasikan mengandung ujaran kebencian Politisch Aktive dan Fremdenfeindlichkeit. Berikut ini merupakan contoh ujaran kebencian Politisch Aktive dan Fremdenfeindlichkeit yang terdapat dalam penelitian ini.
X2: "Wer will?!"

DP: Orang Jerman, pendukung partai $A F D$ dan tidak menyukai para imigran.

Pada komentar tersebut memiliki makna "Siapa yang mau?". Komentar tersebut adalah ujaran kebencian dengan maksud menghina masyarakat yang setuju dengan kebijakan pemerintah Jerman. Penutur yang merupakan orang Jerman beranggapan jika orang-orang yang mau menerima imigran di Jerman pasti bukanlah pendukung partai $A F D$ dan bukan masyarakat Jerman asli. Baginya jika pendukung $A F D$ dan masyarakat Jerman asli, seperti penutur, pasti tidak akan ada yang mau menerima kaum imigran untuk tinggal di Jerman. Komentar tersebut juga berfungsi untuk menyindir orang-orang yang mau menerima kaum imigran. Dengan demikian, sindiran halus yang diungkapkan penutur dapat bermakna "Memangnya siapa yang mau menerima mereka?!".

Kemudian diperoleh 2 data mengandung ujaran kebencian Rassismus dan Fremdenfeindlichkeit karena ditemukan tanda-tanda bahwa penutur yang tidak menyukai imigran mencoba untuk mendeskriminasi dengan menganggap bahwa imigran adalah kaum asing rendahan yang tidak pantas untuk tingga di Jerman maka atas tanda tersebut komentar dapat diklasifikasikan mengandung ujaran kebencian Rassismus dan Fremdenfeindlichkeit. Berikut ini merupakan contoh ujaran kebencian Rassismus dan Fremdenfeindlichkeit.

X3: "Unsere Leute sind ihnen überlegen. Warum akzeptieren Sie das Niedrige!!!".

DP: Orang Jerman, penganut paham nazisme, dan tidak menyukai imigran. 
Komentar tersebut bermakna "Rakyat kita lebih unggul dibandingkan mereka. Mengapa pemerintah menerima kaum rendahan!!!”. Komentar tersebut adalah ujaran kebencian dengan maksud menghina dan merendahkan kaum imigran. Melalui kalimat Unsere Leute sind ihnen überlegen penutur secara tidak langsung menganggap bahwa masyarakat Jerman adalah kaum yang unggul dibandingkan dengan kaum lainnya. Penutur menilai masyarakat Jerman tidak perlu menerima orang asing yang berbeda golongan dengannya. Komentar tersebut berfungsi untuk menyindir pemerintah Jerman dan kaum imigran melalui kalimat Warum akzeptieren Sie das Niedrige!!!. Penutur menilai kaum imigran hanyalah kaum rendahan yang tidak pantas bersanding bersama kaum Arya Jerman. Baginya tidak ada yang bisa menandingi ras Arya Jerman. Ras Arya Jerman yang dianggap penutur lebih unggul dari golongan lainnya. Dengan kata lain, penutur menolak adanya para imigran di Jerman.

Lalu terdapat 1 data mengandung ujaran kebencian Politisch Aktive, Antisemitismus dan antimuslimischer Rassismus karena ditemukan tanda penghinaan yang ditujukan kepada Angela Merkel akibat relokasi imigran ke Jerman dan penghinaan kepada kaum muslim dan yahudi yang dianggap penutur akan menimbulkan konflik di Jerman maka atas tanda tersebut komentar diklasifikasikan mengandung ujaran kebencian Politisch Aktive, Antisemitismus dan antimuslimischer Rassismus. Berikut ini merupakan contoh ujaran kebencian Politisch Aktive, Antisemitismus dan antimuslimischer Rassismus.
X4: "Von Zeit zu Zeit wird dieses Land eine Basis für Juden und Muslime. Bravo Merkel!!"”.

DP: Orang Jerman, tidak menyukai orang Yahudi dan Islam.

Komentar tersebut bermakna "Semakin lama, Jerman akan menjadi tempat berkumpulnya para Yahudi dan kaum Muslim. Hebat Merkel!!!”. Komentar tersebut adalah ujaran kebencian dengan maksud menghina agama Islam dan Yahudi. Penutur memandang kedua agama tersebut tidak memiliki hubungan baik sehingga ditakutkan jika kedua belah pihak akan berkonflik di Jerman. Komentar tersebut berfungsi untuk menyindir para imigran. Melalui kalimat Von Zeit zu Zeit wird dieses Land eine Basis für Juden und Muslime penutur secara tidak langsung menyindir kaum imigran beragama Islam dan Yahudi yang dianggap penutur akan menjadikan Jerman sebagai markas bagi mereka.

Selanjutnya, pada kalimat Bravo Merkel!! penutur secara tidak langsung menyindir Angela Merkel atas kebijakan yang dicanangkannya pada 2015. Penutur menganggap jika kebijakan tersebut tetap diteruskan maka negara Jerman semakin lama akan menjadi markas besar bertemunya kedua belah pihak yang berkonflik di Timur Tengah.

Berikut ini adalah contoh lain dari ujaran kebencian antimuslimischer Rassismus.

X5: "Das sind kriminelle und aggressive Jugendliche islamofaschistische Migranten. Bald kommt dann such der Familiennachzug". 
DP: Orang Norwegia, anti Islam dan anti Palestina.

$\begin{array}{lrr}\text { Komentar } & \text { tersebut } & \text { bermakna } \\ \text { "Merekalah } & \text { pemuda } & \text { imigran }\end{array}$

Islamofasisme yang kriminal dan agresif.

Tak lama lagi akan tiba reuni keluarga". Komentar tersebut adalah ujaran kebencian dengan maksud menghina kaum muslim. Melalui kalimat Das sind kriminelle und aggressive islamofaschistische Migranten penutur secara langsung menunjukkan rasa tidak sukanya pada imigran, terutama imigran muslim. Imigran muslim dianggapnya sebagai orang-orang yang identik dengan kekerasan, pemberontakan dan terorisme. Komentar tersebut juga berfungsi untuk menyindir para imigran melalui kalimat Bald kommt dann such der Familiennachzug. Baginya jika para pengungsi muda berhasil masuk ke Jerman dan kemudian berhasil membawa keluarga mereka maka hal tersebut akan menjadi momen berkumpulnya kembali kelompok beraliran Islamofasisme di Jerman. Penutur menganggap hal itu dapat menjadi ancaman bagi negara Jerman karena bagi penutur orang-orang yang beragama Islam itu identik dengan adanya kekerasan, pemberontakan, dan terorisme.

Selanjutnya, diperoleh 1 data mengandung ujaran kebencian Homo- dan Transphobie karena ditemukan tanda bahwa penutur menganggap imigran LGBT akan menyebarkan penyakit bagi masyarakat Jerman sehingga penutur tidak suka jika kaum imigran LGBT direlokasikan ke Jerman dan atas tanda tersebut komentar diklasifikasikan mengandung ujaran kebencian Homo- dan Transphobie. Berikut ini merupakan contoh ujaran kebencian Homo- dan Transphobie.

X6: "Stellen Sie nur sicher, dass sie keine abweichende sexuelle Orientierung haben".

DP: Orang Jerman dan tidak menyukai LGBT.

Komentar tersebut bermakna "Anda pastikan saja bahwa, para imigran itu tidak memiliki orientasi seksual yang menyimpang". Komentar tersebut adalah ujaran kebencian dengan maksud menghina kaum imigran laki-laki. Imigran dikaitkan penutur memiliki orientasi LGBT, sedangkan penutur tidak menginginkan adanya imigran dengan orientasi seksual LGBT karena kaum LGBT dianggapnya memiliki orientasi seksual yang menyimpang. Komentar tersebut berfungsi untuk menyindir pemerintah Jerman. Penutur menilai pemerintah Jerman tidak perlu menerima pengungsi yang berorientasi seksual LGBT. Dengan kata lain, penutur menolak adanya kaum LGBT untuk tinggal di Jerman.

Selanjutnya, diperoleh 1 data mengandung ujaran kebencian Politisch Aktive dan Sexismus karena terdapat tanda tuduhan penutur pada pemerintah Jerman yang menggunakan pajak hanya untuk kepentingan imigran saja serta terdapat tanda penutur mendeskriminasi imigran perempuan yang hanya bisa memproduksi anak saja maka atas tanda tersebut dapat diklasifikasikan mengandung ujaran kebencian Politisch Aktive dan Sexismus. Berikut ini merupakan contoh ujaran kebencian Politisch Aktive dan Sexismus. 
X7: "Unsere Bevölkerung hier wird an den Rand gedrängt. Es gibt viele Migrantinnen, die hier viele Kinder zur Welt bringen, und Sie möchten hier noch mehr Migrantinnen hinzufügen? Also zahle ich Steuern, nur um sie zu finanzieren?".

DP: Seorang pria yang tidak menyukai imigran perempuan. Komentar tersebut bermakna "Populasi kita di Jerman semakin tersingkirkan. Banyak imigran perempuan yang melahirkan banyak anak di Jerman dan pemerintah masih ingin menambah imigran perempuan lagi di Jerman? Jadi saya membayar pajak hanya untuk membiayai mereka?“. Komentar tersebut adalah ujaran kebencian dengan maksud merendahkan kaum imigran perempuan. Melalui kalimat Unsere Bevölkerung hier wird an den Rand gedrängt. Es gibt viele Migrantinnen, die hier viele Kinder zur Welt bringen, und Sie möchten hier noch mehr Migrantinnen hinzufügen? penutur memiliki rasa takut akan tergesernya populasi asli masyarakat Jerman jika pemerintah merelokasikan imigran perempuan. Penutur menganggap imigran tersebut hanya dapat melahirkan banyak anak saja maka hal tersebut dapat menjadi ancaman bagi populasi masyarakat Jerman. Dengan bertambahnya populasi imigran perempuan di Jerman maka dikhawatirkan penutur akan menimbulkan permasalahan baru, seperti kurangnya tempat tinggal bagi masyarakat Jerman. Komentar tersebut berfungsi untuk menyindir pemerintah Jerman melalui kalimat Also zahle ich Steuern, nur um sie zu finanzieren?. Penutur menyindir pihak pemerintah Jerman bahwa uang pajak yang selama ini dibayarkannya digunakan pemerintah Jerman hanya untuk membiayai kehidupan para imigran di Jerman. Dengan begitu, penutur merasa jika pajak yang selama ini ia dibayarkan terasa sia-sia karena tidak bermanfaat bagi masyarakat Jerman sendiri.

Pada penelitian ini ditemukan data komentar mengandung ujaran kebencian Politisch Aktive, serta Politisch Aktive dan Sexismus. Dari kedua data tersebut ditemukan hubungan antar keduanya. Contohnya pada data X1 dan X7 penutur memiliki kesamaan mengkritik perempuan dalam komentarnya. Dari data X1 dan X7, penutur mengungkapkan rasa kecewanya pada pemerintah Jerman. Pemerintah Jerman dinilai lebih memprioritaskan nasib imigran dibandingkan dengan masyarakat Jerman. Meskipun begitu, juga ditemukan perbedaan antar kedua komentar tersebut. Pada data 1 penutur tidak memiliki motif merendahkan peran dan fisik perempuan. Penutur hanya bertujuan mengkritik Merkel atas kebijakan politik pintu terbuka yang dibuatnya maka pada data X1 hanya mengandung ujaran kebencian Politisch Aktive.

Sedangkan pada data X7 selain penutur mengungkapkan rasa tidak suka pada pemerintah Jerman, ia juga secara tidak langsung merendahkan peran dan fisik perempuan yang dianggapnya lemah dalam kehidupan. Perempuan dianggap penutur sebagai makhluk yang membebani karena hanya bisa memproduksi anak saja maka pada data X7 mengandung ujaran kebencian Politisch Aktive dan Sexismus. Selanjutnya, pada data X1 dan X2 penutur memiliki kesamaan tidak menyukai pemerintah Jerman yang saat ini menjabat. 
Bagi mereka hal tersebut dibuktikan dari sikap pemerintahan Jerman yang kewalahan dalam menanggulangi jumlah pengungsi yang masuk ke Jerman.

Dengan demikian, pemerintah Jerman perlu mengeluarkan biaya ekstra untuk membantu para imigran. Namun, juga terdapat perbedaan yang ditemukan dari kedua komentar tersebut. Pada data X1 rasa tidak suka difokuskan penutur hanya untuk pemerintah Jerman maka pada data $\mathrm{X} 1$ hanya mengandung ujaran kebencian Politisch Aktive saja. Sedangkan pada data $\mathrm{X} 2$ penutur bukan hanya tidak suka kepada imigran, namun ia juga mengeluh kepada pemerintah Jerman yang dianggapnya tidak membantu anak-anak miskin di Jerman maka pada data 10 mengandung ujaran kebencian Politisch Aktive dan Fremdenfeindlichkeit.

Pada penelitian ini ditemukan data komentar mengandung ujaran kebencian Politisch Aktive, Antisemitismus dan antimuslimischer Rassismus, serta antimuslimischer Rassismus. Dari kedua data tersebut ditemukan hubungan antar keduanya. Contohnya pada data X4 dan X5 penutur memiliki kesamaan tidak menyetujui kebijakan baru yang dicanangkan pemerintah Jerman. Penutur memiliki pandangan tidak suka terhadap imigran muslim. Meskipun begitu, terdapat perbedaan pada kedua komentar tersebut. Pada data X4 penutur tidak hanya menolak imigran muslim dan Yahudi bahkan ia menjelekkan, menyindir dan menghina pemerintah Jerman. Dengan demikian, pada data X4 mengandung ujaran kebencian Politisch Aktive, Antisemitismus dan antimuslimischer Rassismus.
Sedangkan pada data X5 kritikan penutur secara spesifik ditujukan hanya untuk menghina kaum muslim maka pada data X5 hanya mengandung ujaran kebencian antimuslimischer Rassismus.

Dari data yang diteliti ditemukan beberapa hal yang mendukung penutur dalam berkomentar, yaitu budaya asal mempengaruhi penutur untuk berkomentar, seperti orang Asia yang biasa mengungkapkan suatu hal melalui sindiran. Sedangkan orang Eropa biasa mengungkapkan sesuatu secara langsung; paham ideologi yang dianut oleh penutur mempengaruhi cara pandangnya dalam berkomentar, seperti orang-orang dari paham nazisme yang lebih mengunggulkan rasnya sendiri dan paham sosialisme yang menginginkan pemerataan kemakmuran bagi penganutnya; agama atau kepercayaan yang dianut oleh penutur, seperti penutur umat kristiani yang ingin kaum seimannya diprioritaskan dahulu untuk dibantu pemerintah Jerman; permasalahan seputar krisis ekonomi Jerman yang membuat penutur enggan menerima kaum imigran; budaya patriarki penutur, seperti imigran wanita yang dipandang lemah oleh penutur; serta pandangan penutur akan suatu partai yang dinilainya tidak memilik tujuan selaras dengan yang diinginkannya.

\section{Kesimpulan}

Hasil penelitian ini dapat disimpulkan bahwa ujaran kebencian pada penelitian ini di dominasi dengan bentuk Politisch Aktive. Penutur menyalahkan pemerintah atas kebijakan relokasi imigran ke Jerman. Kebijakan tersebut dinilai 
mereka (penutur) tidak tepat diterapkan saat negara Jerman mengalami resesi perekonomian. Pada penelitian ini terdapat 5 (lima) bentuk ujaran kebencian berdasarkan teori AJS NRW (2016: 6-11), yaitu Rassismus dan Fremdenfeindlichkeit; Antisemitismus dan antimuslimischer Rassismus; Sexismus, Homo- dan Transphobie; serta Politisch Aktive.

Dalam penelitian ini dibuktikan dengan hasil yang menunjukkan bahwa komentar warganet di akun Facebook DW Deutsch pada artikel berita imigran didominasi dengan ujaran kebencian Politisch Aktive. Hal tersebut dapat berdampak pada penilaian dan rasa tidak percaya yang diberikan mereka (penutur) terhadap pemerintah Jerman saat ini. Dampak lain yang dimunculkan berupa terlihatnya berbagai ujaran kebencian dengan kata-kata mengandung ujaran kebencian yang memang digunakan dalam tuturan di media sosial, serta fungsi ilokusi yang memungkinkan mengandung ungkapan kebencian dalam bahasa media sosial. Akibat dari adanya hal tersebut, yaitu orang-orang yang membaca komentar kebencian di media sosial dapat terprovokasi dan ikut serta melayangkan komentar kebencian.

\section{Daftar Pustaka}

BAMF. "Aktuelle Zahlen 2020." Accessed March 15, 2020. https://www.bamf.de/SharedDocs/A nlagen/DE/Statistik/AsylinZahlen/a ktuelle-zahlen-januar2020.pdf?_blob=publicationFile\&v $=3$.

Baryadi, I. Praptomo. "Kalimat Tidak Berklausa dalam Bahasa Indonesia." Jurnal Widyaparwa, 47 no. 1 (Juni 2019): 57-68. https://widyaparwa.com/index.php/ widyaparwa/article/download/291/p df_1.

Braun, Virginia, et al. "Using thematic analysis in psychology. Qualitative Research in Psycology." Research Repository 3 (2) (December 2006): 77-101. https://doi.org/10.1191/1478088706 qp063oa.

Deutsche Welle. "Deutschland will jungen Flüchtlingen helfen.” Accessed April 5, 2020.

https://www.dw.com/de/deutschland -will-jungen-fl\%C3\%BCchtlingenhelfen/a-

52688183?fbclid=IwAR2YTEgn59

Zc4NUOT-

XTo5uDHom_ByTgc317NoDnUDS saDEwtiseOIenZxg.

DW Deutsch, "Deutschland will jungen Flüchtlingen. helfen." Facebook, March 9, 2020. https://m.facebook.com/dw.german/ posts/10157267668292956/.

Eckhard, Hans. Das Bundesamt in Zahlen. Kassel: Silber Druck oHG, 2019. https://www.bamf.de/SharedDocs/A nlagen/DE/Statistik/BundesamtinZa hlen/bundesamt-in-zahlen2019.pdf;jsessionid=E3ADB4C62E 61A4EE846484041A9DC1EF.inter net552?_blob $=$ publicationFile $\& v=$ 5.

ECRI. Allgemeine Politik-Empfehlung Nr. 15 der ECRI über die Bekämpfung von Hassrede. Straßburg, 2016. https://rm.coe.int/ecri-generalpolicy-recommendation-no-15-oncombating-hatespeech/16808b5b01.

Kessel, Katja. et al. Basiswissen Deutsche Gegenwartssprache $\quad\left(5^{\text {th }} \quad\right.$ ed.). Tübingen: Narr Francke Attempto Verlag GmbH + Co. KG, 2017.

Krifka, Manfred. Sprechakte und Satztypen 
Hauptseminar Sommersemester. Berlin: University of Humbolt, 2004. https://amor.cms.huberlin.de/ h2816i3x/Lehre/2005_H S_Sprechakte/Sprechakte_01_02_Ei nfuehrung_Austin.pdf.

Kushartanti. Pesona Bahasa (3 ${ }^{\text {rd }}$ ed.). Jakarta: PT. Gramedia Pustaka Utama, 2009.

Leech, Geoffry. Principles of Pragmatics, $1^{\text {st }}$ ed. New York: Longman Inc, 2014.

Meibauer, Jörg. Hassrede / Hate Speech Interdisziplinäre Beiträge zu einer Diskussion. Gießen: Elektronische Bibliothek, 2013. http://geb.unigiessen.de/geb/volltexte/2013/10121 /pdf/HassredeMeibauer_2013_korr. pdf\#page $=10$.

NRW, AJS. Hate Speech Hass im Netz. Wuppertal: Börje Halm Press, 2019. https://doi.org/10.4324/9781315699 868-310.

Rizky, Nurul. et al. "Penggunaan Media Sosial Instagram Haloa Cafe Sebagai Komunikasi Pemasaran Online." Junal Ilmu Komunikasi 10, no. 2 (Oktober 2020): 177-90. https://doi.org/https://doi.org/10.156 42/jik.2020.10.2.177-190.

Siri, Jasmin. Kampfzone Gender. Berlin: Nicolai Publishing \& Intelligence GmbH, 2018.

Stelzner, Michael A. "Social Media Marketing Industry Report." Social Media Marketing, 2019. https://drive.google.com/file/d/1znP GOq0IGdJVJlI7rbhimpL7gk-GhvL/view?usp=sharing.

United Nations. "Strategy and Plan of actions on Hate Speech." Accessed August 14, 2021. https://www.un.org/en/genocideprev ention/documents/UN\%20Strategy
\%20and\%20Plan\%20of\%20Action

$\% 20$ on\%20Hate\%20Speech\%2018

\%20June \%20SYNOPSIS.pdf.

Yendra. Mengenal Ilmu Bahasa (Linguistik) ( $1^{\text {st }}$ ed.). Yogyakarta: Deepublish, 2018. 